\title{
LAND COVER CHANGES AND SHALLOW LANDSLIDING IN THE FLYSCH SECTOR OF THE SPANISH PYRENEES
}

\author{
José M. García-Ruiz (1), Santiago Beguería (2), Luis Carlos Alatorre (1) and Juan
}

Puigdefábregas (3)

(1) Instituto Pirenaico de Ecología, CSIC, Campus de Aula Dei, Apartado 13034, 50080-Zaragoza, Spain. humberto@ipe.csic.es

(2) Estación Experimental de Aula Dei, CSIC, Campus de Aula Dei, Apartado 13034, 50080-Zaragoza, Spain. sbegueria@eead.csic.es

(3) Estación Experimental de Zonas Áridas, CSIC, 04001-Almería, Spain. jpuigdefa@eeza.csic.es

\section{Abstract}

This study investigated the characteristics, triggering factors, and spatial distribution of shallow landslides in relation to historical deforestation in the sub-alpine belt of the Pyrenees, particularly in the flysch sector. Shallow landslides in this area occur on straight and concave slopes, mainly covered by mesophyte grasslands, and contribute substantially to soil erosion and landscape deterioration. The investigated landslides were variable in shape and size, although common features included delimitation by a scar or semi-circular crown (averaging $32 \mathrm{~m}$ long x $10.15 \mathrm{~m}$ wide) and a tongue with a lobe at the foot of the scar area. The sliding surface coincided with the zone of contact of the $\mathrm{C}$ soil horizon with the bedrock, although in $13 \%$ of the cases the sliding surface occurred within the soil. The frontal lobes frequently trigger new landslides because of water accumulation and instability, resulting in a succession of interconnected landslides that can attain 100-200 m in length. Slope gradient appeared to be the most important factor correlated with shallow landslides. Thus, with slopes $>30^{\circ}$ the soil was unstable and tended to slide even in dry conditions, whereas with slopes $<15^{\circ}$ the soil was stable even under saturated conditions; shallow landslides were consequently concentrated on slopes between $15^{\circ}$ and $30^{\circ}$. Rapid deforestation of the sub-alpine belt during the Middle and Modern Ages caused a sudden increase in hillslope instability. The studied landslides occurred only on deforested, grassland-covered hillslopes, and not in adjacent forested areas. Therefore, deforestation is considered to be a major factor contributing to shallow landslides, because of changes in soil hydrology and reduced soil strength as a consequence of decreased root cohesion, mainly coinciding with snowmelt and large rainstorms. 
36 Key words: Shallow landslides, Deforestation, Sub-alpine belt, Soil strength, Pyrenees.

\section{Introduction}

Land cover changes cause large alterations in the hydromorphological functioning of hillslopes, affecting rainfall partitioning, infiltration characteristics, and runoff production, and even the shear strength of the soil. In general, deforestation arising from land clearing, forest logging, and/or forest fires results in marked increases in runoff and sediment yield and the triggering of shallow landslides (Van Beek and Van Asch, 2004), thus changing the landscape, the spatial organization of water flows, sediment yield, and the magnitude and frequency of floods. A number of studies have reported the development of shallow landslides in mountain areas as a consequence of deforestation and the substitution of forests by grasslands (e.g., Collinson et al., 1995; Fennin et al., 1996); in New Zealand this had dramatic effects following the expansion of sheep flocks (Crozier and Preston, 1999; Glade, 2003). The increase during the Middle and Modern Ages in the number of sheep in the Alps (Gamper, 1994), Scotland (Ballantyne, 1994), and the Pyrenees (García-Ruiz and Valero-Garcés, 1998) caused lowering of the solifluction belt (Höllermann, 1985) and a generalized increase in soil erosion (García-Ruiz et al., 1990). The expansion of farming onto steep and more marginal hillslopes triggered many shallow landslides evolving into debris flows (Lorente et al., 2002; Bathurst et al., 2007), the effects of which are still present many years after farmland abandonment (Beguería, 2006; Bathurst et al., 2007).

The flysch sector of the Pyrenees occupies a large area between 600 and 2,200 m a.s.l. The sector has been intensively farmed and grazed since prehistoric times, and most south-facing slopes were deforested for cultivation with cereals. To enlarge the area of sub-alpine grasslands the upper forest limit was lowered from 2,100 m to about 1650 m (García-Ruiz and Puigdefábregas, 1982). Different types of mass movement have been identified in previous studies, including shallow landslides in the midmountain and sub-alpine belts, as well as deep slumps and earth-flows (Puigdefábregas and García-Ruiz, 1983, 1984; García-Ruiz and Puigdefábregas, 1984); these latter are directly related to the structural organization of the flysch sector and to the presence of large overthrusting faults (Martí-Bono et al., 1997). The present study investigated the characteristics, trigger factors, and spatial distribution of shallow landslides in relation to historical deforestation in the sub-alpine belt of the Pyrenees, particularly in the 
flysch sector, where landslides contribute substantially to soil erosion and landscape deterioration.

\section{The study area}

The flysch sector is one of the structural units of the central southern Pyrenees, between the Inner Sierras (Cretaceous and Eocene limestones and sandstones) and the Inner Pyrenean Depression (Eocene marls) (Figure 1). The sector is composed of alternating thin layers of Eocene sandstones and marls that are extremely faulted and folded in a WNW-ESE direction, and has developed a complex structure overthrusting toward the south. In general, the relief is characterized by smooth divides, which represent old, probably pre-Quaternary erosion surfaces (Barrère, 1966; Serrano, 1998). The hillslopes are almost straight and have gradients of $30-60 \%$. A variety of erosion processes has resulted in the development of rills, isolated gullies, active headwaters of ravines, and scars of landslides. The rivers in the flysch sector reflect high torrential activity, with prevailing braided channels and bars composed of coarse sediments (D50 = 80-125 mm for the "b” axis) (Martínez-Castroviejo and García-Ruiz, 1990), suggesting high geomorphic activity on the hillslopes (Beguería et al., 2006).

Figure 2 shows the geomorphological map of a sector eastward Biescas, in the Gállego Valley, illustrating on the location of shallow landslides close to the divides. The map also informs about the presence of incising ravines and active headwaters. This suggests a relatively recent and generalized enhancement of the geomorphic activity in the upper part of the hillslopes.

Average annual precipitation ranges from $800 \mathrm{~mm}$ in the lowest parts to 2,200 $\mathrm{mm}$ in the divides (at about 2,200 $\mathrm{m}$ a.s.l.), and mainly falls during the cold season (October to May), particularly in spring and autumn. Summer is relatively dry, although intense rainstorms can occur (García-Ruiz et al., 2000). A rainstorm of 100 mm day-1 corresponds to a 9-year return period, whereas a rainstorm of $150 \mathrm{~mm}^{\text {day }}{ }^{-1}$ corresponds to a 91 years return period. The most intense rainfalls are slightly related to altitude (White et al., 1997). Figure 3 indicates the average monthly precipitation at two locations in the study area: Aratorés (920 m a.s.l.) and Canfranc (1160 m a.s.l.). The two stations have a similar monthly precipitation pattern, but Canfranc receives higher precipitation mainly due to its higher altitude $(1,853 \mathrm{~mm}$ per year, $1,186 \mathrm{~mm}$ in Aratorés). The monthly totals show in both cases a maximum in October or November, and a minimum in July and August. More interesting for debris-flow triggering is the 
occurrence of extreme precipitation events, both in terms of daily intensity (mm day ${ }^{-1}$ ) and of the total event's magnitude ( $\mathrm{mm}$ of rain accumulated over two or more consecutive rainy days). The Figure 3 informs on the monthly values of a 5-year return period event's intensity and magnitude at the two locations, showing that high values (above 200 and $120 \mathrm{~mm}$ of magnitude and 75 and $50 \mathrm{~mm}$ of intensity for Canfranc and Aratorés, respectively) are not frequent. The monthly regime of extreme precipitation is similar in both stations, with a clear maximum of the event's magnitude in November coinciding with the rainfalls related to the Polar Front. For the event's intensity there is a principal maximum in June (Aratorés) and November (Canfranc) and a secondary one in November (Aratorés) and June (Canfranc).

113 Snowfall and snow accumulation are significant above 1,600 m a.s.l. (Del Barrio

114 et al., 1990). From December to March snowfall represents about 80\% of the total 115 precipitation at $1600 \mathrm{~m}$, and 100\% above 1,900 m (García-Ruiz and Puigdefábregas, 116 1982). The average temperature is $5^{\circ} \mathrm{C}$ at approximately 2,000 a.s.l. (Puigdefábregas, 1969). In winter the top $10 \mathrm{~cm}$ of the soil remains frozen.

Above the upper forest limit (about 1600-1700 m) the hillslopes are covered by grasslands of Nardus stricta, Bromus erectus, Festuca eskya and F. scoparia, which are grazed with sheep and cattle flock in summer. However, these hillslopes were originally covered by dense forests of Pinus sylvestris and P. uncinata, as well as beech trees in the higher topographic hollows, and some forest remnants and isolated trees remain up to 2,200 m. Study of sediment accumulation in the sub-alpine glacial Tramacastilla Lake has provided information on changes in plant cover and its hydrological and geomorphological effects (Montserrat, 1992). Since de-glaciation the lake has been subject to fine sedimentation for thousands of years, with an increase in organic matter since the beginning of the Holocene and a generalized expansion of forests. However, a marked ash layer dated at 900 years BP represents a period of deforestation caused by forest fires. Forests were replaced by grasses, the grain size of the sediment increased, and the rate of (mainly detritic) sedimentation increased by several orders of magnitude. Thus, deforestation resulted in a sudden increase in soil erosion caused by rilling, gullying, and landsliding (García-Ruiz et al., 1990).

\section{Methods}

A geomorphological map on scale of 1:50,000 (García-Ruiz and Puigdefábregas, 1982) was used to assess the spatial distribution of landforms, and in particular, the 
137 different types of landslides. The area occupied by each landform was calculated, and 138 the relationships among landforms, land cover, and topographic features (altitude, 139 gradient and aspect) were assessed. Aerial photographs taken between 1956 and 1977 140 were used to select nine areas between the Esca and Ara valleys affected by shallow 141 landslides (Figure 1). A total of 45 landslides were selected and characterized with 142 respect to important quantitative and qualitative attributes (length, width and depth of 143 the landsliding plane, and gradient).

144 In each area the soil profile was exposed and soil samples were taken at every 10 $145 \mathrm{~cm}$ of depth for assessment of grain size distribution (the Bouyoucos-Casagrande 146 method was used, involving prior removal of carbonate and organic matter), and for 147 simple mechanical tests including (i) plasticity, using the Casagrande spoon, and (ii) the 148 apparent specific weight, determined by measuring the volume of water displaced by 149 paraffined soil lumps. These tests enabled the estimation of porosity, saturated specific 150 weight, and saturation humidity, using a value of $2650 \mathrm{~kg} \mathrm{~m}^{-3}$ for the specific weight of the particles. Fluidity at saturation (Fs) is expressed in terms of plasticity as:

$$
\mathrm{Fs}=(\mathrm{SH}-\mathrm{PL}) / \mathrm{PI}
$$

where $\mathrm{SH}$ is the saturation humidity, PL is the plastic limit, and PI is the plastic index. of undisturbed and paraffined soil blocks at the School of Civil Engineers of Barcelona.

\section{Results}

\section{Spatial distribution of shallow landslides}

159 Shallow landslides were found in the Central Spanish Pyrenees between 1,500 160 and 2,200 $\mathrm{m}$ a.s.l., with a maximum frequency at 1,900-2,000 $\mathrm{m}$ (11\% of the total area 161 occupied by this altitudinal class), that is, close to the main divides (Figures 4 and 5). 162 This suggests that shallow landslides are spatially restricted to the sub-alpine belt, on 163 mesophyte grasslands that developed after deforestation in the Middle and Modern 164 Ages, as it was demonstrated by the presence of an ash layer dated in the Middle Ages 165 and changes in the pollen composition of lacustrine sediments (Montserrat, 1992). 166 These landslides always formed on deep soils, largely free of stones. $75 \%$ of them occurred on gradients ranging from 13 and $25^{\circ}$ of gradient (Figure 6), with $18.8^{\circ}$ as average gradient, ranging between 9 and $31^{\circ}$. The absence of landslides on steeper slopes is because of the previous dismantling of deep soils (Figure 7), probably 
170 immediately after deforestation, such that bedrock reached the surface or was covered by a thin regolith affected by gelifluction terracettes.

Shallow landslides also occur at 1,200-1,400 m on hillslopes that are currently reforested with pine and shrub communities, but which have historically been affected by frequent human-induced fires, overgrazing, and shifting agriculture (Lorente et al., 2002 and 2003). These landslides occur on a stony colluvium and not on deep soils, and typically evolve into unconfined hillslope debris flows.

\section{Characteristics of shallow landslides}

The shallow landslides investigated were of variable shape and size, although common features were evident (Figures 8 and 9):

(i) The landslides were delimited by a scar or semi-circular crown with an average length of $32 \mathrm{~m}$ when the flysch was weakly calcareous, and $17 \mathrm{~m}$ when the flysch was highly calcareous. The average scar width was about 10-15 m, and the scar was delineated by the presence of a short scarp of $40-60 \mathrm{~cm}$.

(ii) At the foot of the scar there was an accumulation talus of 1-2 $\mathrm{m}$ in length caused by erosion of the scarp.

(iii) The sliding surface occupied most of the area surrounded by the scar, and bedrock with abundant detached sandstone was evident.

(iv) A tongue composed of landslip material in the form of a lobe developed at the foot of the sliding area, causing a change in the profile of the slope. In some cases the front of the lobe was affected by slow solifluction, caused by both the increased slope at the front and the accumulation of water resulting from overland flow over the bedrock sector.

In general, the landslide surface coincided with the zone of contact between the C soil horizon and the bedrock, although in $13 \%$ of cases the landslide surface was within the soil. Soil depth was $0.5-0.9 \mathrm{~m}$ in the straight part of the slopes, $0.8-1.2 \mathrm{~m}$ in the concave areas, and 0.3-0.5 $\mathrm{m}$ in the convex areas; this variability explains the depth of the sliding plan and the volume of the frontal lobe. Puigdefábregas and García-Ruiz (1984) also reported that the depth of the sliding surface was related to the plant communities present. In areas dominated by Nardus stricta, the sliding surface tended to be located at an average depth of $0.6 \mathrm{~m}$, whereas in areas dominated by Bromus erectus and Festuca eskya the average depth was $0.9 \mathrm{~m}$. This is interpreted as an effect of soil humidity on the type of plant community present. Nardus stricta grows mainly in 
wet areas, and therefore a shallower soil depth could trigger a landslide because of the greater weight and lower cohesion of humid soils.

Figure 6 shows the evolution of landslides from simple to complex events. A relatively rapid downward evolution of sequential landslides was evident in 28 of the 45 landslides examined (Figure 10). Thus, the frontal lobe of a shallow landslide tended to be a trigger for a new landslide because of water accumulation (overland flow from the bare bedrock immediately upslope) and instability (because of the increased gradient at the front), resulting in a succession of interconnected landslides, in some cases reaching 100-200 m in length.

An upward evolution was also observed because of (i) small falls in the scar,

214 partially induced in spring by pipkrake activity, and (ii) the reactivation of planar slides

215 affecting part of the hillslope, following the development of tension cracks surrounding 216 the scar.

217 The presence of bare areas and lobes reorganized the distribution of plants at a 218 local scale. For instance, species adapted to incipient soils (Onobrychis pyrenaica,

219 Medicago suffruticosa) increased on the bare calcareous areas, whereas on sandy bare areas Lotus corniculatus, Plantago alpina, Trifolium pratense and Hypochoeris radicata prevailed. In the frontal lobes, species requiring higher soil fertility (Agrostis capillaris, Poa alpina, Bellis perennis, Lolium perenne, Trifolium repens) tended to increase, but in the front itself the relative instability of the soil increased the occurrence of Thymus praecox. Hillslopes over $30^{\circ}$ appeared to be totally dismantled and covered by pioneer vegetation (Festuca scoparia) on the external part (steps) of gelifluction terracettes.

\section{Soil characterization}

The grain-size distribution and plasticity were estimated in eight soil profiles in the Sayerry (SA) and Oturia (OT) sampling areas (Table 1). Two of these profiles (SA-0 and OT-0) were on apparently stable divides, another (SA-1) was in an area not affected by mass movement, and the reminder were in the scars of shallow landslides.

Grain-size distribution. Soils were loamy, rich in carbonates, and more clayey in the case of more calcareous flysch (Oturia). Some profiles (SA-2, SA-3 and OT-0) showed "normal" evolution of the profile, with an increase in fines in the lower part. Others (OT-1, OT-2) showed little change in grain size distribution, suggesting that the action of successive landslides had mixed and homogenized the soil profile. Finally, 
two profiles had increased levels of sand in the lower part; these were on a sector of more sandy flysch (SA-1) and in a large solifluction lobe (SA-4).

Plasticity. The plasticity limit (PL) was about 30 in the Sayerri area (sandy

240 flysch) and about 20 in the Oturia area (calcareous flysch). In both regions the fluidity 241 limit (FL) was relatively high (more than 31, and typically over 45). The plasticity 242 index (PI) was quite low in most cases, with the exception of OT-0, which corresponded 243 to an apparently stable divide. The saturation humidity was positive (between 0 and 1) 244 in the most sandy (SA-3 and OT-1) and porous (SA-4) soils, indicating susceptibility to 245 creeping, solifluction, and mudflows.

Stability analysis

248 The friction angle showed little variability $\left(30.3^{\circ} \pm 1.3^{\circ}\right)$, whereas cohesion was much more variable. In Oturia the cohesion value decreased from $21 \mathrm{kPa}$ in the divide to $0 \mathrm{kPa}$ at the foot of the hillslope. However, it is necessary to take into account that the direct cut test is much more precise than is cohesion measurement for determining friction angles. Even so, values of cohesion of 5-8 $\mathrm{kPa}$ seemed to be typical of the study areas.

Based on the hypothesis of planar landslides in an infinite slope, it is conventional to express the stability conditions of a slope using the factor of safety (FS), which is defined as the ratio of the available shear strength $\left(\tau_{f}\right)$ to the shear stress $(\tau)$ (Van Asch, 1980):

$$
F S=\frac{c^{\prime}+(\sigma-\mu) \tan \varphi^{\prime}}{\gamma_{t} z \sin \alpha \cos \alpha}
$$
where $c^{\prime}$ is the effective soil cohesion including the effect of the root strength (kPa), $\sigma$ is the total normal stress $(\mathrm{kPa}), \mu$ is the pore water pressure $(\mathrm{kPa}), \gamma_{t}$ is the unit weight of the sliding material $\left(\mathrm{kN}^{-3} \mathrm{~m}^{-3}\right), \mathrm{z}$ is the vertical sliding thickness $(\mathrm{m}), \alpha$ is the slope angle $\left(^{\circ}\right)$ and $\varphi^{\prime}$ is the effective angle of internal friction $\left(^{\circ}\right)$. A value of $F S=1$ indicates the limit failure criterion, so for $F S>1$ the soil is stable, and is unstable where $F S<1$. As it can be seen, variation of the pore water pressure is the main triggering mechanism

266 in the infinite slope model. Equation (2) can be expressed in terms of the degree of soil saturation as: 
$268 F S=\frac{c^{\prime}+\left(\gamma_{t}-m \gamma_{w}\right) z \cos ^{2} \alpha}{\gamma_{t} z \sin \alpha \cos \alpha} \tan \varphi^{\prime}$,

269 where $\gamma_{w}$ is the unit weight of water $\left(9.81 \mathrm{kN} \cdot \mathrm{m}^{-3}\right)$ and $m$ is the soil saturation (-).

270 Assuming null cohesion, the critical slope angle for failure $\alpha_{\text {crit }}$ can be estimated

271 for two extreme hydrologic conditions:

$272 \quad$ (i) dry soil $(m=0): \alpha_{c r i t}=\varphi^{\prime}$

273

(ii) saturated soil $(m=1): \alpha_{c r i t}=\arctan \left(\frac{\gamma_{t}-\gamma_{w}}{\gamma_{t}} \tan \varphi^{\prime}\right)$

274 The use of measured values to calculate the internal friction angle resulted in a critical 275 angle of $30.33^{\circ}$ for dry conditions and $15.8^{\circ}$ for the saturated situation. Therefore, soils 276 on slopes over $30^{\circ}$ are at risk of breaking even in dry conditions (unconditionally unstable soils), whereas those on slopes of less than $15^{\circ}$ are stable, even when saturated (unconditionally stable). The stability of soils on slopes between these two angles depends on the moisture condition of the soil (conditionally stable soils). This is consistent with field observations, as slopes over $30^{\circ}$ were almost completely bare, and the majority of landslides on deep soils occurred on slopes of $20-25^{\circ}$.

Based on the measured cohesion values, the critical moisture value $m$ for failure of most samples was above 1, implying that the piezometric level had to be greater than the soil and regolith thickness. It is difficult to explain failure under these conditions, except through a local reduction in soil cohesion. It is also possible that preferential flow occurred at the bottom of the soil profile, coinciding with more sandy layers, and that this led to positive water pore pressures. This situation is most likely to occur during the snowmelt period, when water is supplied to the soil in a steady and prolonged manner.

Unfortunately there is no available information on the occurrence time of the landslides, so correlation is not possible with precipitation data that would allow assessing the magnitude of triggering thresholds. We hypothesize, however, that shallow landslides in the area are triggered by high but not too extreme events in terms of rainfall intensity. Triggering seems to be more related to the occurrence of prolonged rainy periods that may accumulate a significant amount of precipitation. At this respect, it is interesting to notice that the long-term time series of the annual highest precipitation event's intensity ( $\mathrm{mm} \mathrm{day}^{-1}$ ) shows increasing trends both for Canfranc and Aratorés, as demonstrated by the Mann-Kendall test (p-values $<0.01$ and 0.03 , 
respectively). The annual highest precipitation event's magnitude ( $\mathrm{mm})$, on the other

300 hand, shows a significant increasing trend in Canfranc ( $\mathrm{p}$-value $=0.02$ ), but not in 301 Aratorés $(\mathrm{p}$-value $=0.54)$. The last may be explained by the fact that Canfranc station 302 (1160 m a.s.l.) is more exposed to the flows of the North and Northwest, and the 303 frequency of these flows show a positive trend in the last decades, especially in the months that recorded more precipitation (spring and autumn; Vicente-Serrano, 2005). The time series are shown in figure 11.

\section{Discussion and conclusions}

Shallow landslides are a very important part of the landscape in the sub-alpine area of the flysch sector of the Central Spanish Pyrenees. They occur mainly above $1500 \mathrm{~m}$ a.s.l., with a higher concentration around 1,900-2,000 m, relatively close to the main divides. They are clearly related to the presence of soils deeper than 40-70 cmdeep, particularly on straight and concave slopes, and landslides were seen principally on mesophyte grasslands. No relationship was found between shallow landsliding and the spatial organization of the fluvial network, as the scars did not connect with upward erosion from the valleys. There was usually diffuse drainage downslope from the frontal lobe, and overland flow disappeared over the grasslands. A study of the spatial organization of geomorphic processes in the Central Pyrenees using geomorphological mapping, SIG, and statistical analysis (González et al., 1995) demonstrated that shallow landslides in the sub-alpine belt are clearly related to human activities, as is also seen with terracettes and debris flows.

Slope gradient appeared to be the most important factor related to the occurrence of shallow landslides. Thus, on slopes over $30^{\circ}$ the soil is unstable and tends to slide even in dry conditions, whereas the soil is stable on slopes of less than $15^{\circ}$, even under saturated conditions. For this reason, shallow landslides were concentrated on slopes of $15^{\circ}-30^{\circ}$. This finding corroborates field observations over a larger area (Puigdefábregas and García-Ruiz, 1984) as hillslopes over $30^{\circ}$ were almost completely bare, and the remnants of deep soils were located principally on slopes between $20^{\circ}$ and $25^{\circ}$, with evidence of landsliding controlled by the sub-superficial water conditions. On slopes of less than $15^{\circ}$ no shallow landslides occurred. Instead, very deep soils (in some cases more than 1.5-2 $\mathrm{m}$ deep, primarily at the foot of the slopes) correlated with the accumulation of material supplied by upslope landslide activity. In other mountain areas shallow landslides are triggered on gradients as steep as $25^{\circ}-38^{\circ}$ (Takahashi et al., 
1981), and $32^{\circ}-42^{\circ}$ (Innes, 1983), although in such cases they evolve into debris flows and can connect directly to the fluvial network. However, most landslides occur on slopes greater than $20^{\circ}$ on weathered graywackes (Blong, 1974) and soft Miocene andesites (Salter et al., 1981); 25 on soft mudstone/sandstone (Crozier et al., 1989); and $33-36^{\circ}$ on hard graywackes (Lawrence et al., 1982). In the sub-alpine belt of the study area no debris flows or mudflows were observed, and each shallow landslide was composed only of a scar and a corrugated lobe at the immediate foot, that often evolved into more complex, interconnected shallow landslides.

Apart from topography, other extrinsic factors (past or present) were found to favour the development of landslides. Rapid deforestation of the sub-alpine belt during the Middle and Modern Ages caused a sudden increase in hillslope instability, resulting in soil erosion, gullying, rilling, and shallow landsliding (Montserrat, 1992; García-Ruiz and Valero-Garcés, 1998). Importantly, the studied landslides occurred only on deforested, grassland-covered hillslopes, and not in adjacent forested areas, where creeping is the only relevant geomorphic process. Therefore, deforestation is a major factor contributing to shallow landslides, because of changes in soil hydrology, and reduced soil strength arising from decreased root cohesion. This latter aspect has been considered the most important factor increasing the rate of landsliding after forest clearance (Wu and Swanston, 1980; Blijenberg, 1998; Cannon, 2000; Van Beek and Van Asch, 2004; Beguería, 2006; Kuriakose et al., 2009).

The main landslide triggering mechanism is the loss of soil cohesion arising from an increase in pore water pressure during periods of intense and/or prolonged rainfall or snowmelt (Van Asch et al., 1999). The average annual precipitation in the sub-alpine belt is about 1,550-2,200 mm, with peaks in autumn and spring. Spring rainfall also coincides with the snowmelt, which is relatively rapid on south-facing slopes and supplies a high volume of water. Not surprisingly, the highest frequency of scars occurred close to the main divides, where snow accumulation is maximal. Nevertheless, the occurrence of shallow landslides seems to be more related to lowfrequency rainfall events (Caine, 1980) than to snowmelt and spring rainfall, particularly in recent decades during which a clear decline in snow accumulation has been detected (López-Moreno, 2005). For instance, comparison of the 1956 and 1978 aerial photographs showed no differences in the size or area occupied by landslides, suggesting that the studied shallow landslides must have a recurrence time of more than 
367 variable rainfall in the sub-alpine belt of the Central and Eastern Pyrenees, with more 368 than $200 \mathrm{~mm}$ falling in some eastern valleys (and >600 $\mathrm{mm}$ in the Cinca Valley), 369 whereas about $100 \mathrm{~mm}$ was recorded in the western valleys (those of Aragón and 370 Gállego). Under these conditions new shallow landslides occurred in the sub-alpine belt 371 (Martí-Bono and Puigdefábregas, 1983), whereas the forested slopes remained stable.

372 Estimating the return period of such rainfall is difficult because of the absence of long373 term meteorological records in high mountain areas. Nevertheless, a return period of 374200 years was estimated for the rainfall that was recorded in the Cinca Valley, but the 375 return period was less than 25 years for rainfall in the Aragón and Gállego valleys 376 (García-Ruiz et al., 1983). However, it is likely that the climatic conditions of the 16th377 18th centuries, during which a deeper snowpack formed, could have intensified the occurrence of shallow landslides.

In the long-term, a synergy between snowmelt and large rainstorms could explain the observed and reported facts. Snowmelt could increase the landslide hazard by decreasing cohesion to zero in any particular place. This risk might occur with an increase in water pore pressure caused by large rainstorms.

\section{Acknowledgements}

Support for this research was provided by the projects PROBASE (CGL200611619/HID, Consolider), financed by the Spanish Commission of Science and Technology, ACQWA (FP7-ENV-2007-1), by the European Commission, and PI032/08

388 financed by the Aragón Regional Government. The authors also acknowledge support 389 from the Program of Research Groups of the Aragón Regional Government, and from 390 RESEL (The Spanish Ministry of Environment). 


\section{References}

394 Ballantyne, C.K., 1994. Holocene mass movement on Scottish mountains: dating, distribution and implications for environmental change. In: B. Frenzel, ed., Solifluction and climatic variations in the Holocene, Special issue ESF, Gustav Fisher Verlag, pp., 71-86.

Barrère, P., 1966. La morphologie quaternaire dans la región de Biescas et de Sabiñánigo (Haut Aragón). Bulletin de l’Association Française pour l’Étude du Quaternaire 2, 83-92.

Bathurst, J.C., Moretti, G., El-Hames, A., Beguería, S., García-Ruiz, J.M., 2007. Modelling the impact of forest loss on shallow landslide sediment yield, Ijuez catchment, Spanish Pyrenees. Hydrology and Earth System Sciences 11 (1), 569583.

Beguería, S., 2006. Changes in land cover and shallow landslide activity: A case study in the Spanish Pyrednees. Geomorphology 74 (1-4), 196-206.

Beguería, S., López-Moreno, J.I., Gómez-Villar, A., Rubio, V., Lana-Renault, N., García-Ruiz, J.M., 2006. Fluvial adjustments to soil erosion and plant cover changes in the Central Spanish Pyrenees. Geografiska Annaler 88A(3), 177-186.

Blijenberg, H., 1998. Rolling stones? Triggering and frequency of hillslope debris flows in the Bachelard Valley, Southern French Alps. Utrecht University, Utrecht.

Blong, R.J., 1974. Landslide form and hillslope morphology: An example from New Zealand. The Australian Geographer 12 (5), 425-438.

Caine, N., 1980. The rainfall intensity-duration control of shallow landslides and debris flows. Geografiska Annaler 62A, 23-27.

Cannon, S.H., 2000. Debris flow response of southern California watersheds burned by wildfire. In: Wieczorec, G.F., Naeser, N.D. (Eds.), Debris flow hazard mitigation: Merchanics, prediction and assessment, Balkema, Rotterdam, pp. 45-52.

Collinson, A.J.C., Anderson, M.G., Lloyd, D.M., 1995. Impact of vegetation on slope stability in a humid tropical environment: a modelling approach. Proceedings of the Institution of Civil Engineers. Water, Maritime and Energy 112, 168-175.

Crozier, M.J., Preston, N.J., 1999. Modelling changes in terrain resistance as a component opf landform evolution in unstable hill country. In: S. Hergartenand H.N. Neugebauer, eds., Process modelling and landform evolution. Lecture Notes in Earth Sciences, Springer, Heidelberg, pp. 267-284. 
426 Crozier, M.J., Eyles, R.K., Marx. S.L., McConchie, J.A., Owen, R.C., 1980. 427 Distribution of landslips in the Wairapa hill country. New Zealand Journal of $428 \quad$ Geology and Geophysics 23, 575-586.

429 Del Barrio, G., Creus, J., Puigdefábregas, J., 1990. Thermal seasonality of the high 430 mountain belts of the Pyrenees. Mountain Research and Development 10 (3), 227431233.

432 Fannin, R.J., Wise, M.P., Wilkinson, J.M.T., Rollerson, T.P., 1996. Landslide initiation 433 and runout on clearcut hillslopes. Proceedings of the 7th International Symposium on 434 Landslides, Trondheim, Norway, pp. 195-199.

435 Gamper, M., 1994. Holocene solifluction in the Swiss Alps: Dating and climatic 436 implications. In: B. Frenzel, ed., Solifluction and climatic variations in the Holocene, 437 Special Issue ESF, Gustav Fisher Verlag, pp. 1-10.

438 García-Ruiz, J.M., Puigdefábregas, J., 1982. Formas de erosión en el flysch eoceno 439 surpirenaico. Cuadernos de Investigación Geográfica 8, 83-126.

440 García-Ruiz, J.M., Puigdefábregas, J., 1984. Inestabilidad de laderas en el Pirineo 441 aragonés: Tipos de movimientos y su distribución geográfica. Jornadas sobre Inestabilidad de laderas en el Pirineo. Barcelona, E.T.S.I. Caminos, pp. 141-152.

García-Ruiz, J.M., Valero, B., 1998. Historical geomorphic processes and human activities in the Central Spanish Pyrenees. Mountain Research and Development 18 (4), 309-320.

García-Ruiz, J.M., Puigdefábregas, J., Martín-Ranz, M.C., 1983. Diferencias espaciales en la respuesta hidrológica a las precipitaciones torrenciales de Noviembre de 1982 en el Pirineo Central. Estudios Geográficos 170-171, 291-310.

García-Ruiz, J.M., Alvera, B., Del Barrio, G., Puigdefábregas, J., 1990. Geomorphic processes above the timberline in the Spanish Pyrennes. Mountain Research and Development 10 (3), 201-214.

García-Ruiz, J.M., Arnáez, J., White, S., Lorente, A., Beguería, S., 2000. Uncertainty assessment in the prediction of extreme rainfall events: an example from the Central Spanish Pyrenees. Hydrological Processes 14, 887-898.

Glade, T., 2003. Landslide occurrence as a response to land use change: a review of evidence from New Zealand. Catena 51 (3-4), 297-314.

González, C., Ortigosa, L., Martí, C., García-Ruiz, J.M., 1995. The study of the spatial 459 organization of geomorphic processes in mountain areas using GIS. Mountain Research and Development 15 (3), 241-249. 
460

461

462

463

464

465

466

467

468

469

470

471

472

473

474

475

476

477

478

479

480

481

482

483

484

485

486

487

488

489

490

491

Höllermann, P., 1985. The periglacial belt of mid-latitude mountains from a geoecological point of view. Erdkunde 39, 259-270.

Innes, J.L., 1983. Debris flows. Progress in Physical Geography 7 (4), 469-501.

Kuriakose, S.L., Van Beek, L.P.H., Van Westen, C.J., 2009. Parameterizing a physically based shallow landslide model in a data poor region. Earth Surface Processes and Landforms, doi: 10.1002/esp.1794.

Lawrence, J.H., Salinger, M.J., Depledge, D.R., Oakley, D.J., 1982. Landslip and flooding hazard in Eastbourne borough: A guide for planning. Water and Soil Miscellaneous Publication, No. 37, Water and Soil Division, Ministry of Works and Development, Wellington, 45 pp.

López-Moreno, J.I., 2005. Recent variations of snowpack depth in the Central Spanish Pyrenees. Arctic, Antarctic, and Alpine Research 37 (2), 253-260.

Lorente, A., García-Ruiz, J.M., Beguería, S., Arnáez, J., 2002. Factors explaining the spatial distribution of hillslope debris flows. A case study in the Flysch Sector of the Central Spanish Pyrenees. Mountain Research and Development 22 (1), 32-39.

Lorente, A., Beguería, S., Bathurst, J.C., García-Ruiz, J.M., 2003. Debris flow characteristics and relationships in the Central Spanish Pyrenees. Natural Hazards and Earth System Sciences 3, 683-692.

Martí-Bono, C., Puigdefábregas, J., 1983. Consecuencias geomorfológicas de las lluvias torrenciales de noviembre de 1982 en la cabecera del Cinca. Estudios Geográficos 170-171, 275-289.

Martí-Bono, C., Valero-Garcés, B., García-Ruiz, J.M., 1997. Large, historical debris flows in the Central Spanish Pyrenees. Physics and Chemistry of the Earth 22 (3-4), 381-385.

Martínez-Castroviejo, R., García-Ruiz, J.M., 1990. Coladas de piedras (debris flows) y dinámica fluvial en ríos torrenciales del Pirineo Central: el caso del río Ijuez. Cuadernos de Investigación Geográfica 16, 55-72.

Montserrat, J., 1992. Evolución glaciar y postglaciar del clima y la vegetación en la vertiente sur del Pirineo: estudio palinológico. Zaragoza, Instituto Pirenaico de Ecología, 147 pp.

Puigdefábregas, J., 1969. Avance para un estudio climatológico del Alto Aragón. Pirineos 79-80, 115-140. 
Puigdefábregas, J., García-Ruiz, J.M., 1983. Parámetros físicos y dinámica de vertientes en el Pirineo Central. VIII Coloquio de Geógrafos Españoles, Barcelona, pp. 131138.

Puigdefábregas, J., García-Ruiz, J.M., 1984. Dynamique des versants au niveau supraforestier: Glissements massifs des sols anciens dans les Pyrénées Centrales. Documents d'Écologie Pyrénéenne 3-4, 449-454.

Salter, R.T., Crippen, T.F., Knoble, K.A., 1981. Store damage assessment of the Thames-Te Aroha area following the storm of April 1981. Soil Conservation Centre Aokauterre, Internal Report No 44, Ministry of Works and Development, Aokauterre, 53 pp.

Serrano, E., 1998. Geomorfología del Alto Gállego, Pirineo aragonés. Zaragoza, Institución Fernando El Católico, 501 pp.

Takahashi, T., Ashida, K., Sawal, K., 1981. Delineation of debris flow hazard areas. In: Erosion and sediment transport in Pacific Rim Steeplands, IAHS Publication 132, 589-603.

Van Beek, L.P.H., Van Asch, T.W.J., 2004. Regional assessment of the effects of landuse change on landslide hazards by jeans of physically based modelling. Natural Hazards 31 (1), 289-304.

Van Asch, T.W.J., Buma, J., Van Beek, L.P.H., 1999. A view on some hydrological triggering systems in landslides. Geomorphology 30, 25-32.

Visente-Serrano, S.M., 2005. Las sequías climáticas en el valle medio del Ebro: Factores atmosféricos, evolución temporal y variabilidad espacial. Zaragoza, Consejo de Protección de la Naturaleza de Aragón, 277 pp.

White, S., García-Ruiz, J.M., Martí, C., Valero, B., Errea, M.P., Gómez-Villar, A. 1997. The 1996 Biescas campsite disaster in the Central Spanish Pyrenees, and its temporal and spatial context. Hydrological Processes 11, 1797-1812.

Wu, Y.H. and Swanston, D.N., 1980. Risk of landslides in shallow soils and its relations to clearcutting in southeastern Alaska. Forest Science 26, 495-510. 
522 Figure captions

523 Fig. 1. The Flysch Sector in the Central Spanish Pyrenees, showing the sampling areas.

524 Fig. 2. Geomorphological map of a selected sector eastward Biescas, Gállego Valley.

525 Fig. 3. Mean monthly precipitation (left axis), and mean maximum event's intensity and

526 magnitude (right axis) of the 5-year return period precipitation event over the period

527 1930-2006 at Aratorés and Canfranc (see Figure 1 for location).

528 Fig. 4. Distribution of shallow landslides according to the altitude. The figure represents

529 the percentage of area affected by landsliding in relation to the total area occupied by

530 the different categories of altitude.

531 Fig. 5. Examples of shallow landslides close to the divides in the sub-alpine belt of the 532 Flysch Sector.

533 Fig. 6. Distribution of shallow landslides according to the gradient. The figure

534 represents the percentage of area affected by landsliding in relation to the total area

535 occupied by the different categories of gradient.

536 Fig. 7. Spatial distribution of deep soils and bedrock outcrops in a hillslope with 537 different gradients.

538 Fig. 8. Types of shallow landslides in the sub-alpine belt of the Flysch Sector. A:

539 Simple type, with the scar, talus, bedrock or sliding plan, and frontal lobe. B:

540 Interconnected or composed landslides. C: Longitudinal profile of simple and composed

541 landslides.

542 Fig. 9. Scar and frontal lobe of a single shallow landslide.

543 Fig. 10. Complex development of shallow landslides.

544 Fig. 11. 1930-2006 time series of the annual highest precipitation event's magnitude

545 (mm, solid circles) and intensity (mm day ${ }^{-1}$, empty line) at Aratorés and Canfranc (see 546 Fig. 1 for location). 
548 Table 1.Physical Soil parameters measured at the shear plane

\begin{tabular}{|c|c|c|c|c|c|c|c|c|}
\hline & SA-0 & SA-1 & SA-2 & SA-3 & SA-4 & OT-0 & OT-1 & OT-2 \\
\hline Location on the slope (1) & $\mathrm{D}$ & $\mathrm{H}$ & $\mathrm{H}$ & $\mathrm{H}$ & $\mathrm{F}$ & $\mathrm{D}$ & $\mathrm{H}$ & $\mathrm{F}$ \\
\hline Landform (2) & $\begin{array}{c}\mathrm{U} \\
0.4- \\
0.6\end{array}$ & $\begin{array}{c}U \\
0.7- \\
0.80\end{array}$ & $\begin{array}{c}\mathrm{O} \\
0.60- \\
0.80\end{array}$ & $\begin{array}{c}\mathrm{U} \\
0.60- \\
0.81\end{array}$ & $\begin{array}{c}\mathrm{L} \\
0.80- \\
1.00\end{array}$ & $\begin{array}{c}\mathrm{U} \\
0.40- \\
0.60\end{array}$ & $\begin{array}{c}\mathrm{U} \\
0.60- \\
0.80\end{array}$ & $\begin{array}{c}\mathrm{U} \\
0.60- \\
0.81\end{array}$ \\
\hline Landslide & No & No & Yes & Yes & Yes & No & Yes & Yes \\
\hline Gradient $\left({ }^{\circ}\right)$ & - & 25 & 24 & 25 & 22 & - & 23 & 20 \\
\hline \multicolumn{9}{|l|}{ Texture (\%) } \\
\hline -Sand & 24.67 & 30.09 & 29.02 & 28.19 & 60.25 & 8.77 & 44.8 & 32.44 \\
\hline -Silt & 40.43 & 46.11 & 43.14 & 43.84 & 28.92 & 42.72 & 30.78 & 44.24 \\
\hline -Clay & 34.90 & 23.8 & 27.84 & 27.97 & 10.83 & 48.51 & 24.42 & 23.32 \\
\hline \multicolumn{9}{|l|}{ Plasticity (3) } \\
\hline -Liquidity Limit (LL) & - & - & 47.2 & 47.5 & $(26.0)$ & 59 & 31.5 & 37.5 \\
\hline -Plastic limit (PL) & - & - & 30.0 & 32.2 & $(19.6)$ & 28.5 & 19.7 & 21.7 \\
\hline -Plastic Index (PI) & - & - & 17.2 & 15.3 & $(6.4)$ & 30.5 & 11.8 & 15.8 \\
\hline Dry Weight $\left(\mathrm{kg} / \mathrm{m}^{3}\right)$ & 1315 & - & 1502 & 1273 & 1629 & 1690 & 1577 & 1618 \\
\hline Porosity (\%) & 50.4 & - & 43.3 & 52 & 38.5 & 36.2 & 41.2 & 38.9 \\
\hline Saturated Weight (kg/m3) & 1819 & - & 1935 & 1793 & 2014 & 2502 & 1969 & 2007 \\
\hline Fluidity at Saturation (FS) & - & - & -0.07 & 0.57 & 0.63 & -0.23 & 0.15 & \\
\hline Friction angle $\left(^{\circ}\right)(j)$ & 23.9 & - & 28.6 & 28.7 & 31.8 & 29.6 & 29.1 & 31.6 \\
\hline Cohesion $\left(\mathrm{kg} / \mathrm{m}^{2}\right)$ & 890 & - & 699 & 699 & 657 & 2103 & 972 & 0 \\
\hline Groundwater Level (4) (m) & - & - & 2.31 & 2.31 & 2.08 & - & 3.25 & 0.79 \\
\hline
\end{tabular}

(1): $\mathrm{D}=$ Divide; $\mathrm{H}$ = Mid slope; and F = Foot of slope.

551 (2): U = Undifferentiated; O: Front of old landslide; $\mathrm{L}=$ Solifluction lobe.

552 (3): The values in parentheses were taken at $60 \mathrm{~cm}$ depth because the sample at $0,0.80-1.00 \mathrm{~m}$ were quite granular.

553 (4): $M=h / z$ where $h$ is the height of the groundwater level from the base of the soil. 


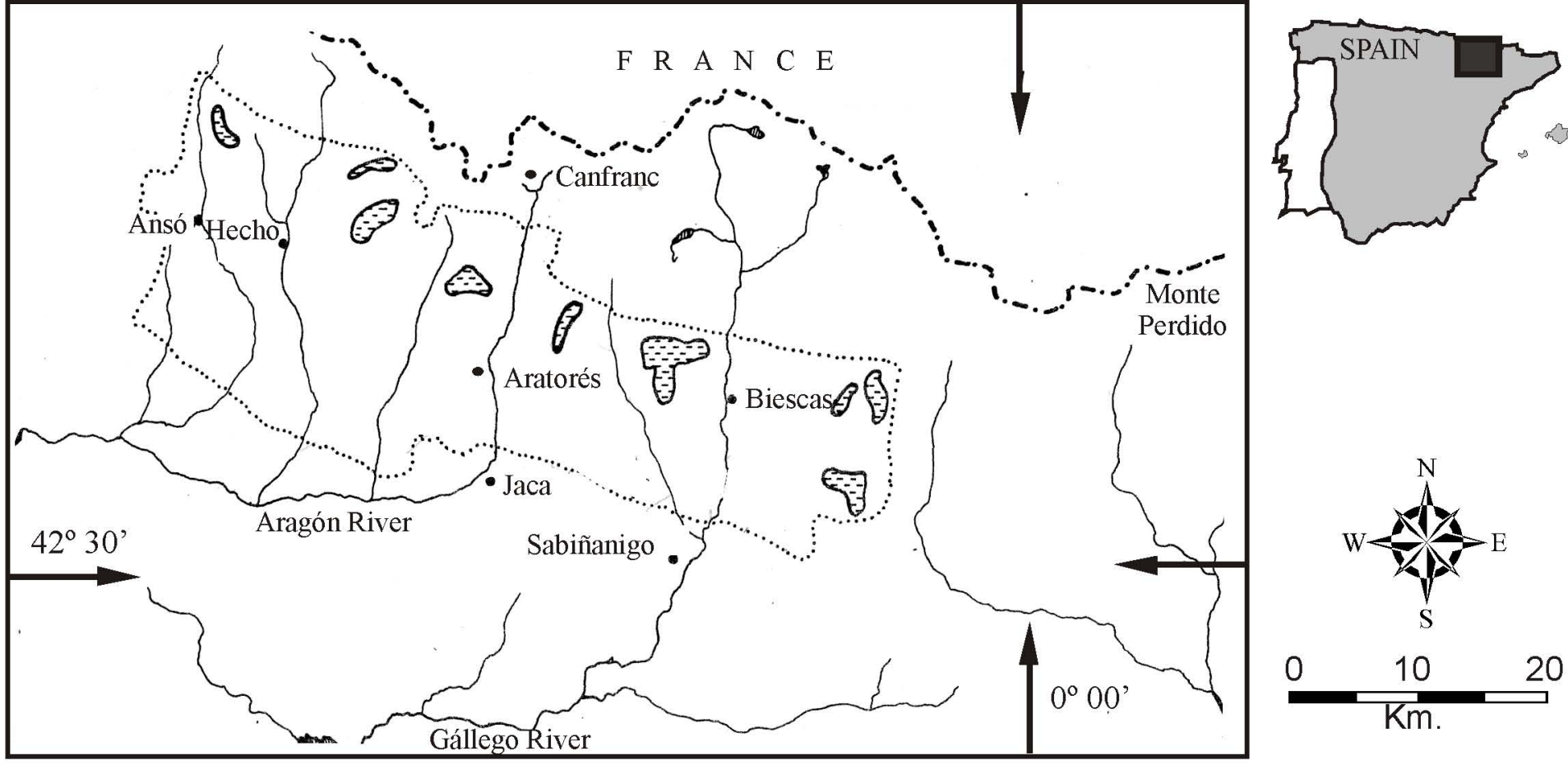

$\therefore \cdots . . \quad$ STUDY AREA

SHALLOW LANDSLIDES SAMPLING AREAS 


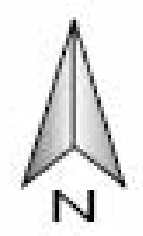

\begin{tabular}{|c|c|}
\hline$=$ & Small cliffs \\
\hline OIVIO & Old erosion levels \\
\hline$-\cdots$ & Rounded divide \\
\hline$\sqrt{4+4}$ & "Cuesta" front \\
\hline 温: & Glacial tills \\
\hline 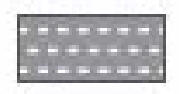 & Ice-dammed lacustrine deposits \\
\hline & Streams \\
\hline M & Waterfalls \\
\hline 6. & Alluvial fan \\
\hline c & Solifluction lobe \\
\hline 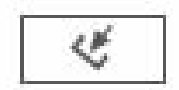 & Shallow landslide \\
\hline a & Debris flows \\
\hline$M$ & Active headwater \\
\hline
\end{tabular}

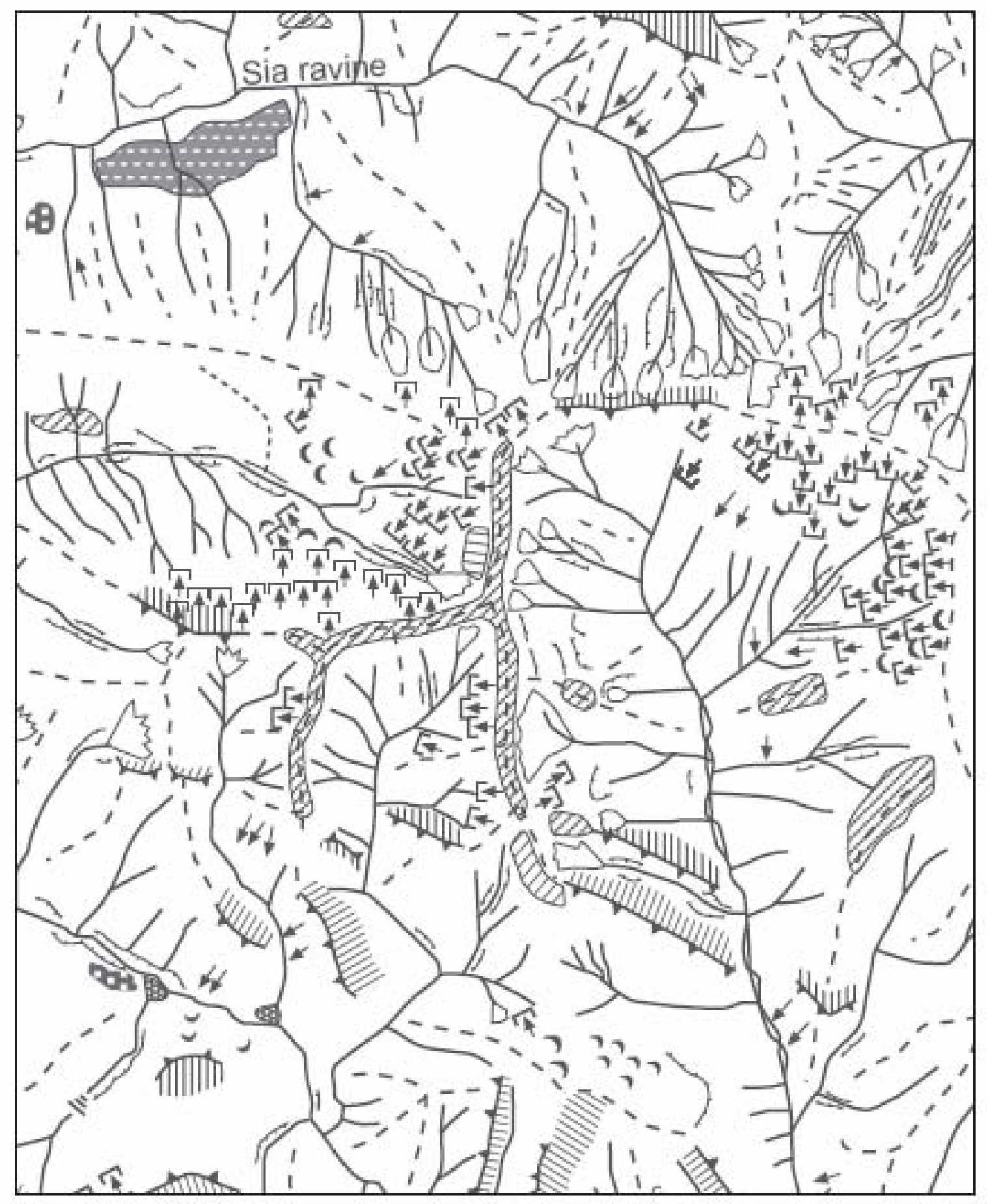




\section{Canfranc}

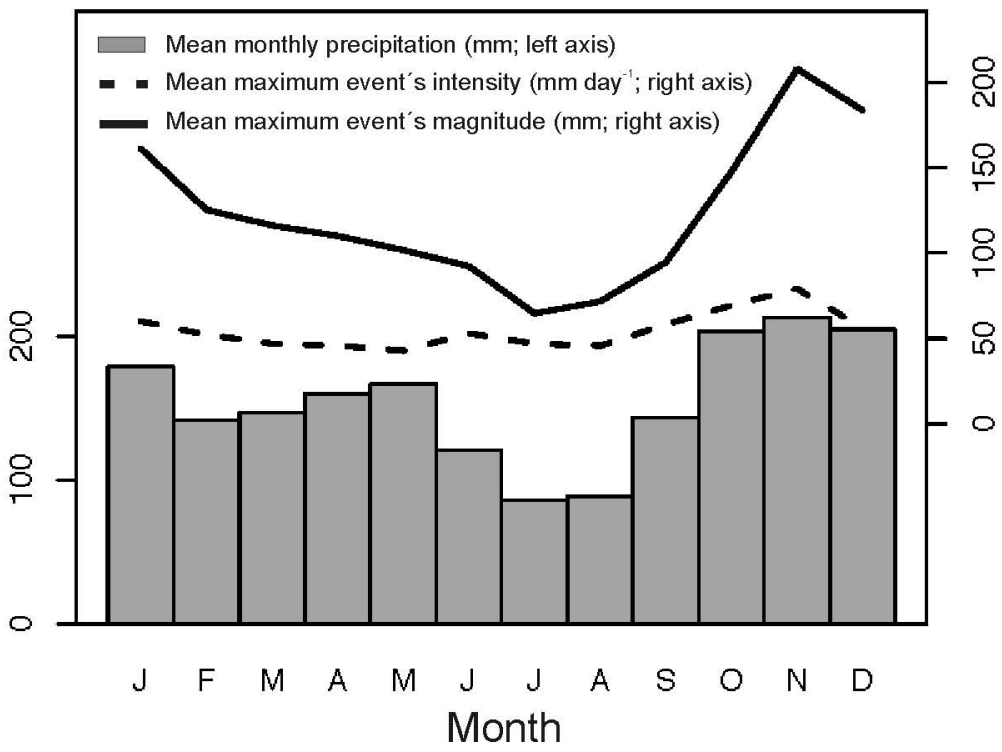

\section{Aratorés}

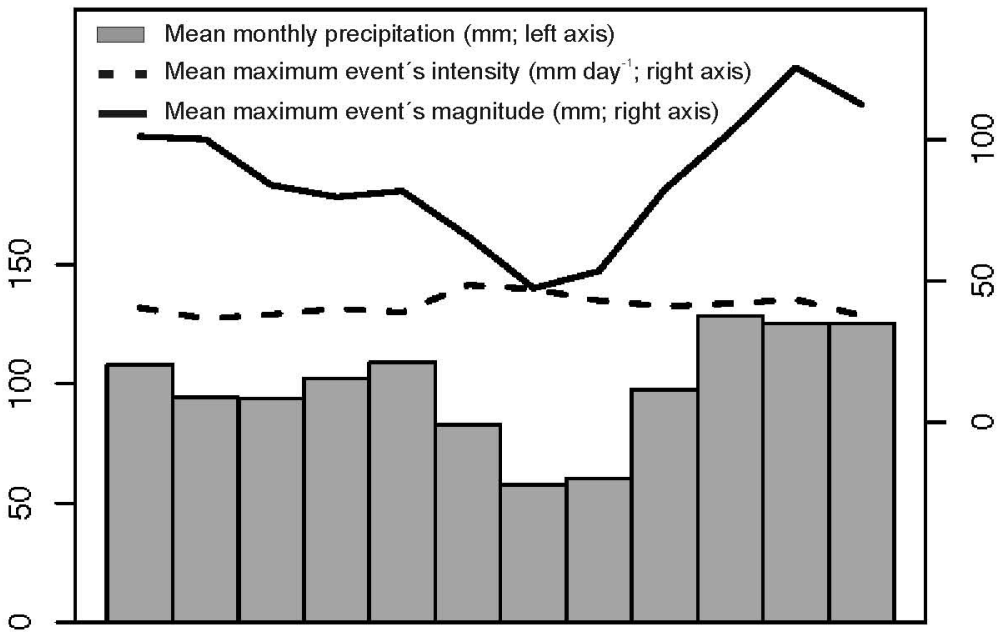

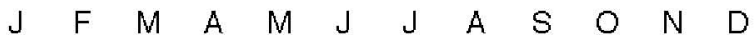
Month 


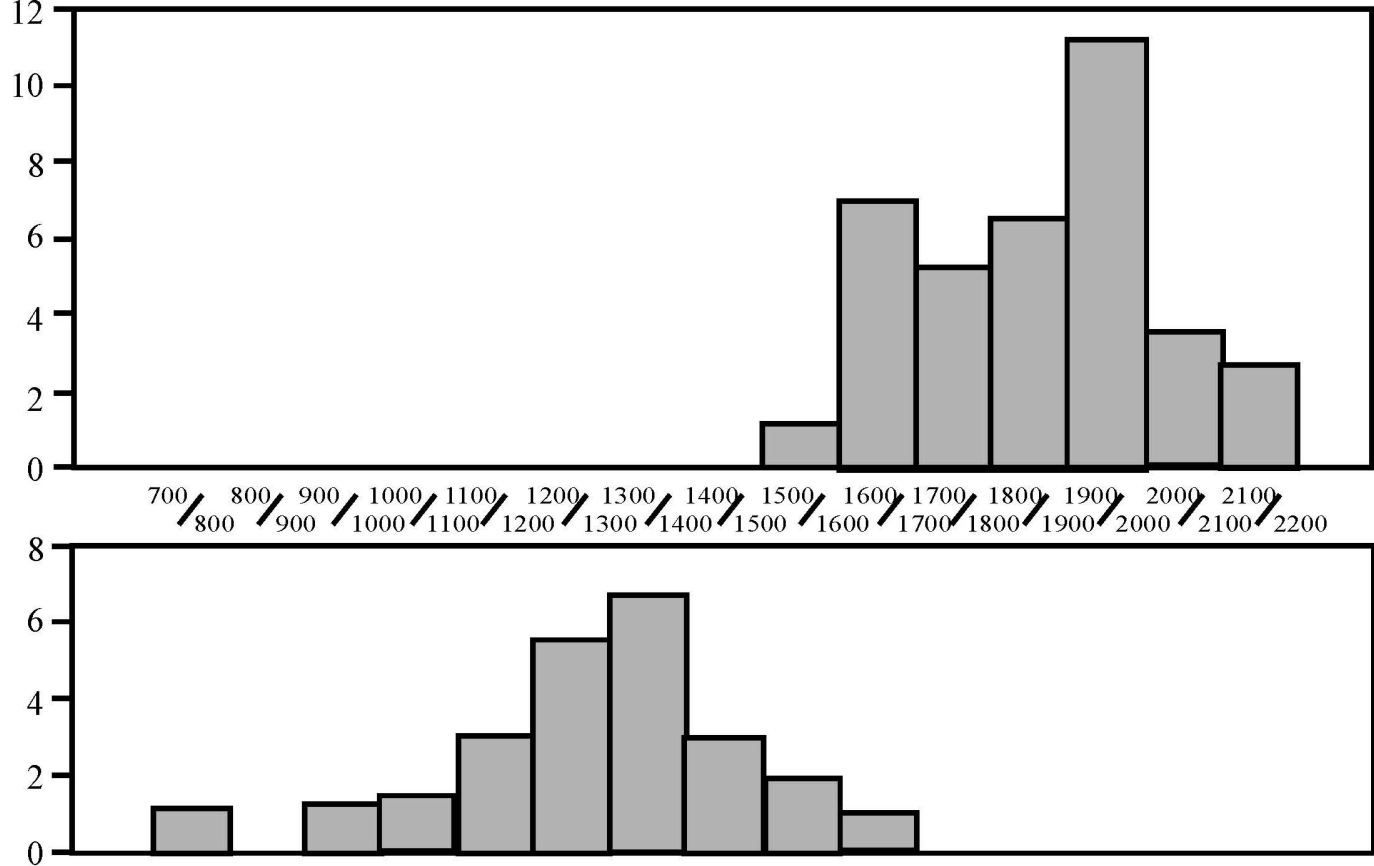

\section{ALTITUDE (m)}




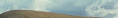

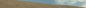

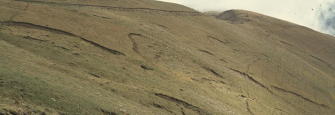

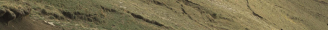

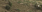

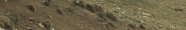

S.

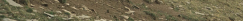

Whe

$-3 \times-4=$ 
II)

○

20

2

$\mathrm{Z} \quad 16$

$\square$

$\alpha$

[I]

$\mathrm{O}$

$>$

2

12

8.

4.

10

20

30

$\operatorname{SLOPE}\left({ }^{\circ}\right)$ 


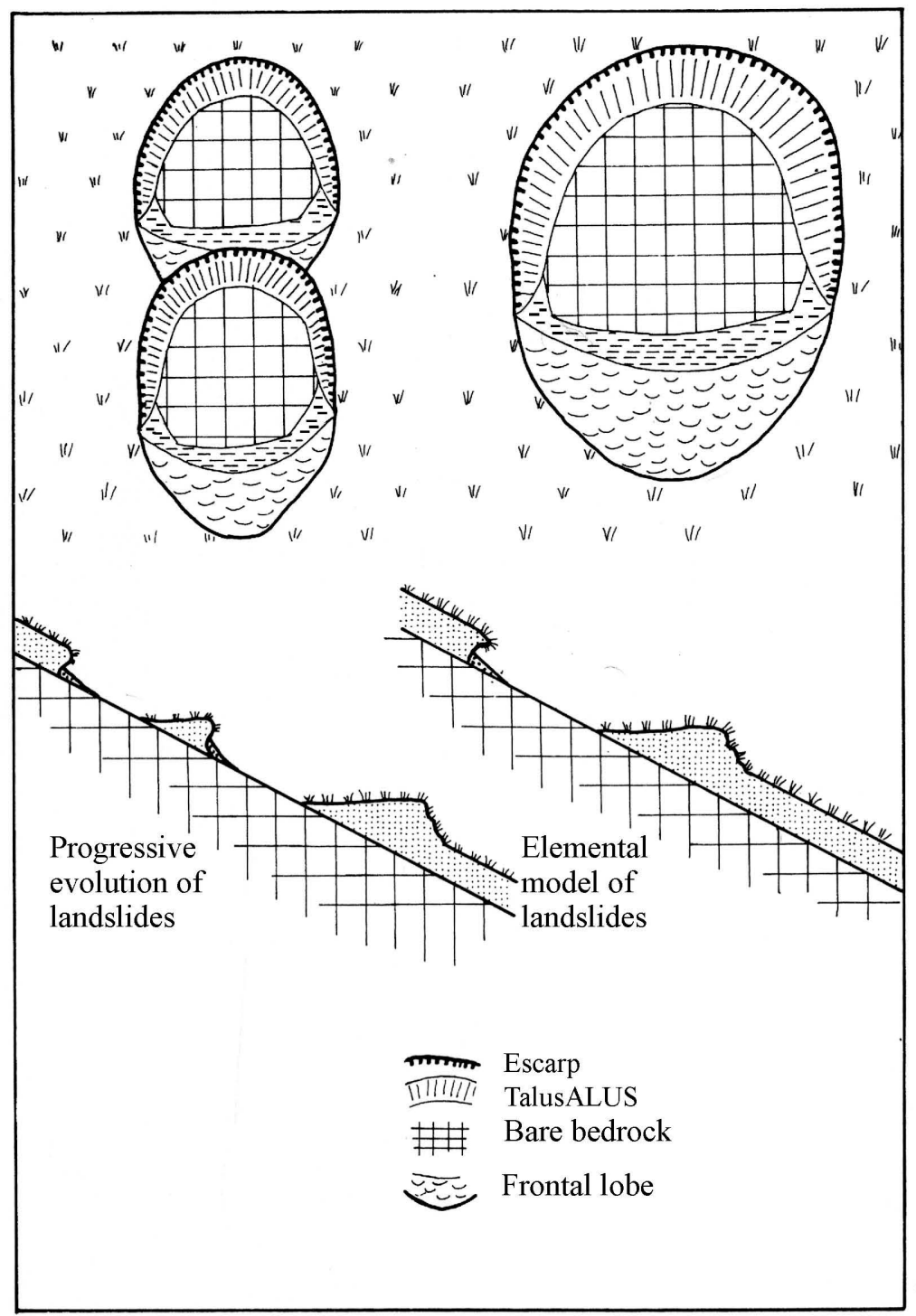




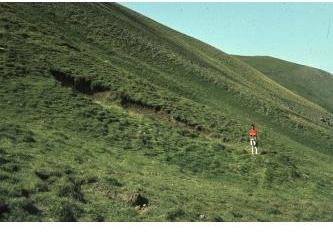




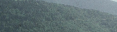

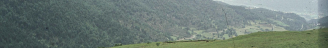

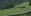

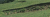

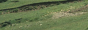

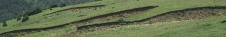

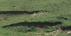

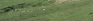

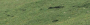

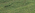


Canfranc

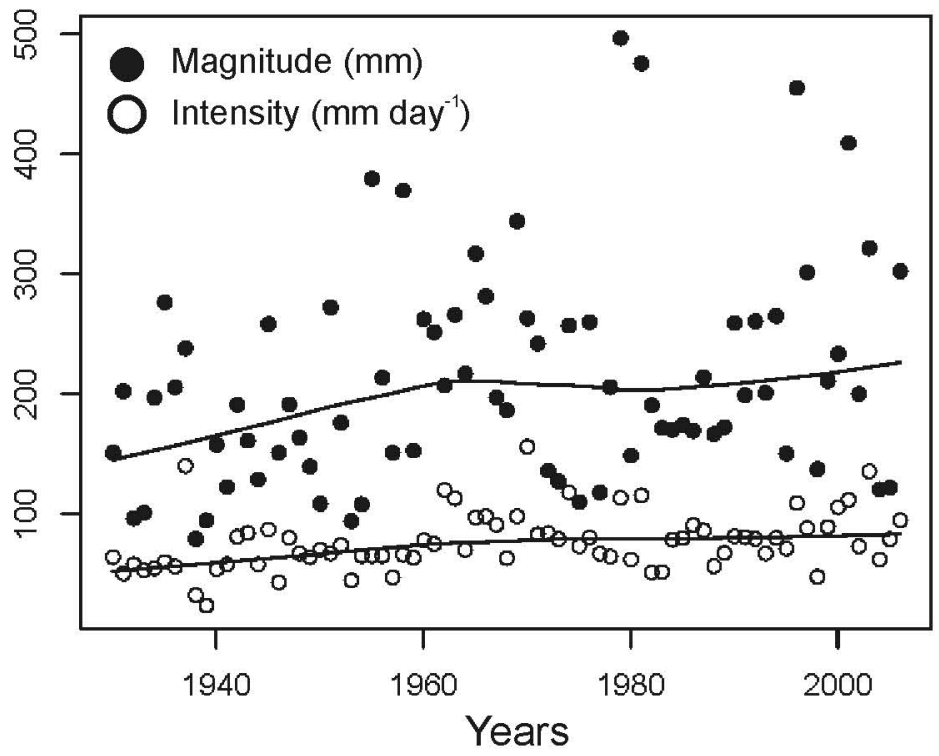

Aratorèss

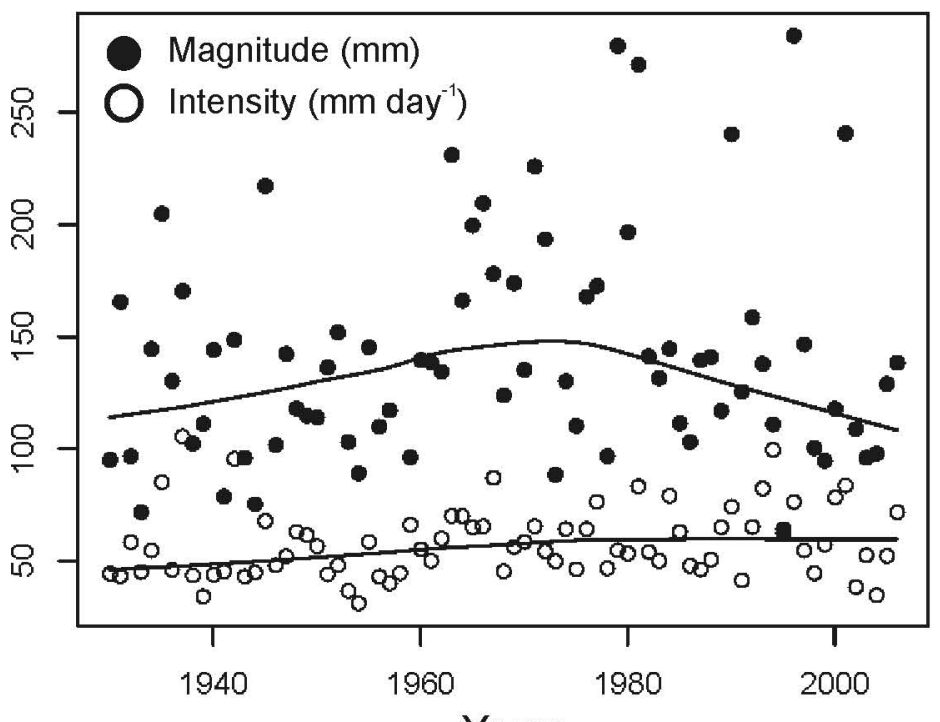

